\title{
Al-Rada'ah Perspektif Hadis
}

\author{
Muhammad \\ Email: muhammad.wakka@umi.ac.id \\ Dosen Tetap Universitas Muslim Indonesia
}

\begin{abstract}
Abstrak
Al-Rada'ah menurut syara yaitu proses menyedot putting pada usia kurang lebih dua tahun pada anak kecil telah sampai air susu manusia pada lambungnya. Rukun alRada'ah terdapat 2 poin, yaitu anak yang menyusu dan wanita yang menyusui baik dewasa, dalam keadaan haid, hamil atau tidak. Syarat al-Rada'ah terdapat 5 poin, yaitu: air susu yang diberikan kepada anak susuan harus dihasilkan dari hubungan yang sah, Air susu itu masuk kerongkongan anak, Masuknya air susu boleh melalui jalan mulut ataupun lewat hidung, dan meneteknya masih dalam usia bayi. Selain hukum syara' al-Qur'an dan hadis juga membahas tentang al-Rada'ah. Terdapat beberapa hadis yang membahas tentang al-Rada'ah dengan sudut pandang yang berbeda-beda, seperti: bilangan dan bentuk susuan yang dapat mengharamkan, menyusui orang dewasa dan lain sebagainya. Adapun hikmah dari al-Rada'ah pembesaran tulang dan penumbuhan daging akibat pasokan makanan yang berupa susu. Dengan demikian, maka perempuan yang menyusui menjadi ibu susuan karena dia adalah bagian dari anak itu secara hakikat.
\end{abstract}

Kata kunci : al-Rada'ah dan hadis

\section{Pendahuluan}

Hadis merupakan salah satu sumber ajaran Islam yang telah disepakati oleh seluruh ummat muslim baik yang berupa larangannya, sama halnya dengan kewajiban mengikuti al-Qur'an. Hal ini, karena hadis merupakan mubayyin bagi al-Qur'an, yang karenanya siapapun yang tidak bisa memahami al-Qur'an tanpa dengan memahami dan menguasai hadis. Begitu pula halnya menggunakan hadis tanpa al-Qur'an karena al-Qur'an merupakan dasar hukum pertama, yang di dalamnya berisi garis besar syariat. Dengan demikian, antara hadis dengan al-Qur'an memiliki kaitan untuk mengimami dan mengamalkan hal ini antara al-Qur'an dan hadis saling berkaitan satu sama lain.( Utang Wijawa: 1996, 19).

Para ulama mengkaji al-Qur'an dan hadis melalui gagasan-gagasan dan pikiran mereka yang tertuang dalam kitab-kitab tafsir, syarah, maupun kitab-kitab fiqh. Walaupun dalam kenyataannya kajian terhadap al-Qur'an lebih banyak ditemukan karena para ulama lebih mengendalikan diri dan mengutamakan sikap reserve (segan) untuk melakukan telaah ulang dan pengembangan pemikiran terhadap hadis secara apresiasif karena khawatir adanya anggapan inka $>r$ al-sunnah. ( Abdul Majid Khon: 2009, 29.) 
Al-Qur'an dan hadis apabila diteliti lebih mendalam akan sampai pada titik simpul bahwa selain sebagai sumber ajaran Islam dan sebagai sumber ilmu pengetahuan lainnya. Pengetahuan agama yaitu hal-hal yang gaib yang sumber tunggalnya wahyu, seperti hadis-hadis yang menjelaskan tentang Allah, malaikat, kitab-kitab-Nya, rasul-rasul-Nya, dan hari akhir, fenomena akhir zaman serta penekanan terhadap berita gembira (al-mubsyirat) maupun pengetahuan yang berkaitan dengan aspek kemanusiaan seperti hadis-hadis yang menjelaskan tentang ekonomi pendidikan, kedokteran dan lain-lain.

Salah satu ajaran dalam hadis yaitu "penyusuan anak" (al-rada'ah) secara eksplisit dan tegas dikemukakan di dalam Kitab Suci al-Qur'ân dan kemudian mendapatkan penjelasan dari hadits Nabi SAW. Sebagaimana pada umumnya dalam al-Qur'ân dan hadis, ajaran itu masih membuka ruang interpretasi tafsir dan hadis yang luas. Hampir semua kitab fiqh dari pelbagai madzhab membahas topik alrada'ah dalam pasal tersendiri di bawah pembahasan bab "nikâh".

\section{Pembahasan}

A. Syarah hadis tentang al-Rada'ah

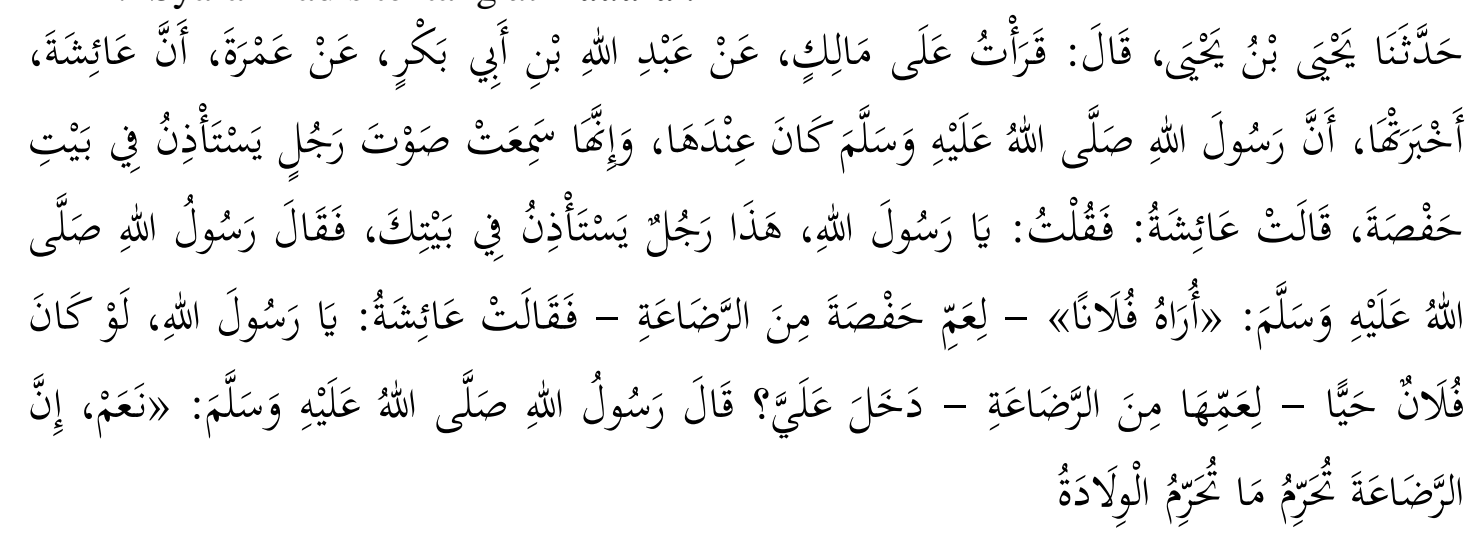

(Muhammad bin Ismail Abu ‘Abdullah al-Bukhari al-Ju’fi: 1422, 170.)

Artinya:

Dari Aisyah RA, bahwa suatu ketika Rasulullah berada dirumah Aisyah. Saat itu Aisyah mendengar suara laki-laki yang meminta izin masuk kerumah Hafshah. Aisyah berkata, "Ya Rasulullah! laki-laki itu meminta izin kerumah engkau ." lalu beliau menjawab, "aku lihat dia adalah anak si fulan, (anak paman Hafshah dari saudara susuan)". kata Aisyah," aku berkata, "wahai Rasulullah! seandainya fulan hidup (paman Aisyah dari saudaran susuan) apakah dia boleh masuk kerumahku?" beliau menjawab, "Ya boleh, karna susuan itu menyebabkan mahram sebagaimana hubungan kelahiran."

Syarah kalimat 


$$
\text { لَوْ كَانَ فُفَلَنْ حَيَّا }
$$

Kata fulan yang dimaksud adalah Aflah saudara kandung abi al-Qais karena لَز كَانَ حَيَّا itu menunjukkan bahwa telah tiada maka kemungkinan adalah keduanya bersaudara boleh jadi keduanya wafat dalam waktu yang berbeda. (Ahmad bin Ali bin Hajar al-Asłqalani: 1989, 174-175).<smiles>[Al]C#CC#CC#C[As]</smiles>

Secara ijma' yang berkaitan dengan haramnya nikah saudara sesusuan yakni Air susu yang diberikan kepada anak susuan harus dihasilkan dari hubungan yang sah. Maksudnya adalah jika air susu itu mengalir bukan disebabkan karena nikah melainkan dari hubungan zina, maka air susu tersebut tidak menyebabkan kemahraman. Dalam kalimat ini al-Qurtubi pendapat telah terjadi dua periwayatan pertama ما تُرَّمِ الْوَلَادَة dan riwayat kedua ما يحرم من النسب riwayat ini menunjukkan riwayat bil makna dan bahkan kedua riwayat ini terjadi periwayatan dalam satu waktu.

Al-Qurtubi berpendapat hadis tersebut menjelaskan bahwa saudara sepersusuan menunjukkan pengharaman perkawinan antara keduanya. Diharamkan perkawinan tersebut karena mensyaratkan sebagai ibunya. (Ahmad bin Ali bin Hajar al-Asqalani: 1989, 174-175).

\section{Pandangan Ulama Tentang Al-Rada'ah}

Rada'ah secara bahasa adalah proses menyedot putting yang dilakukan oleh hewan manupun manusia. Sedangkan menurut syara"e yaitu pada usia kurang lebih dua tahun pada anak kecil telah sampai air susu manusia pada lambungnya. Abdurrahman al-Jaziri: t.th, 219) Selain itu rada 'ah menurut syara "e juga didefiniskan penyedotan anak yang menyusu pada puting manusia dalam waktu tertentu. rada' $a h$ merupakan penyusuan yang dilakukan dalam sekali, sebagaimana lafadz darbatan (satu kali pukul) jalsatan (satu kali duduk) dan aklatan (satu kali makan), ketika seorang anak kecil menyedot puting susu kemudian meninggalkan dengan kemauannya sendiri tanpa paksaan maka hal tersebut dinamakan rada'ah. (Muhammad Ibn Ali Ibn Muhammas al-Syaukani: 1995, 310).

Dari Aisyah berkata Sahla binti suhail menghadap kepada rasulullah lalu berkata ya rasulullah sesungguhnya saliman ibnu Khuzaifah telah datang kepada kami dan telah sampai pembicaraan kami tentang pernikahan kepada seorang lakilaki lalu nabi menjawab apakah dia saudara sepersusuan? Maka haram atasnya. Dalam sunan Abu Dawud yaitu menyusui sampai lima kali menyusui, orang yang telah menyusui hal tersebut sudah menjadi saudara sepersusuan. Sepersusuan orang 
dewasa haram meskipun tidak termasuk dalam kategori sepersusuan karena bukan menjadi kebutuhannya. (Wahbah Zuh \}aily: 1997, 6637)

1. Rukun dan syarat al-rada'ah

a. Rukun al-Rad'ah

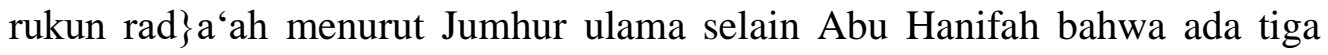
yaitu:

1) Anak yang menyusu

2) Wanita yang menyusui menurut beberapa pendapat para ulama disyaratkan adalah seorang wanita, baik dewasa, dalam keadaan haid, hamil atau tidak. Akan tetapi ulama berbeda pendapat tentang air susu dari wanita yang sudah meninggal.( Ibnu Rusyd: 1988, 39-40) Menurut Imam Syafie $i$ susu harus berasal dari wanita yang masih hidup, sedangkan menurut Imam Hanafi dan Malik boleh meskipun tersebut sudah mati. (Abdurrahman al-Jaziri: t.th, 219)

b. Syarat al-Rada'ah

Syarat sesusuan yang mengharamkan nikah menurut pandangan jumhur ulama adalah: (Wahbah Zuhaily: 1997, 72).

1) Air susu yang diberikan kepada anak susuan harus dihasilkan dari hubungan yang sah. Maksudnya adalah jika air susu itu mengalir bukan disebabkan karena nikah melainkan dari hubungan zina, maka air susu tersebut tidak menyebabkan kemahraman. (Muhammad Jawad Mughniyah: 1996, 340)

Air susu harus berasal dari seorang wanita baik masih perawan maupun sudah berkeluarga atau janda. Jika yang diminumkan itu selain susu, seperti munum air kuning, darah, atau air muntahan maka tidak haram menikahi, sama halnya jika susu yang diminum itu dari seseorang lelaki, banci, atau dari binatang ternak. Jika ada dua orang bayi lelaki dan perempuan meminum susu kambing maka keduanya tidak menjadi saudara meskipun satu susuan karena susu yang diminum bukan dari seorang wanita. Dan keduanya halal untuk menikah karena tidak terhitung saudara, sedangkan persaudaraan itu cabang dari keibuan. Jika tidak ada pangkal maka tidak ada cabang. (Wahbah Zuhaily: 1997, 6637).

Ulama Syafieiyyah mensyaratkan wanita yang menyusui itu masih hidup atau sudah cukup umur atau baligh yaitu mencapai usia sekitar tujuh tahun dari hitungan hijriyah. Artinya nikah tidak menjadi manjadi haram dengan meminum susu wanita yang sudah meninggal dunia atau susu perempuan yang belum cukup umur.

Akan tetapi jika seorang wanita dewasa memeras air susunya sendiri sebelum meninggal dunia, kemudian susu tersebut diminumkan kepada bayi setelah wanita tersebut meninggal dunia maka menurut pendapat yang sah hukum nikahnya tetap haram karena keluarnya air susu tersebut ketika si wanita dalam keadaan hidup.

Akan tetapi mayoritas ulama tidak mensyaratkan syarat tersebut maksudnya meskipun air susu wanita yang sudah meninggal dan air susu dari anak kecil yang belum mampu melakukan senggama. Akan tetapi jika air susunya diminum dengan alasan karena air susu itu akan menjadi daging dan air susu itu tidak mati. 
2) Air susu itu masuk kerongkongan anak, baik melalui isapan langsung dari putting payudara maupun melalui alat penampung susu seperti gelas, botol dan lain-lain. Menurut madzab empat terjadinya rad a 'ah tidak harus melalui penyedotan pada puting susu, akan tetapi pada sampainya air susu pada lambung bayi yang dapat menumbuhkan tulang dan daging. Namun mereka berbeda pendapat mengenai jalan lewatnya ASI, menurut Imam Malik dan Hanafi harus melewati rongga mulut, sedangkan menurut Hambali adalah sampai pada lambung dan pada perut atau otak besar. (Wahbah Zuh \}aily: 1997, 6637).

3) Masuknya air susu boleh melalui jalan mulut ataupun lewat hidung. Para ulama sepakat bahwa pengharaman nikah kerena $\mathrm{rad}\} \mathrm{a}^{\text {'ah }}$ bisa tercapai dengan mengalirnya air susu melalui mulut, dan bisa juga dengan mengalirnya air susu melalui hidung sampai keotak. Menurut Hanafiyah dan Syafie yah dalam pendapat azhar, dan Hanabilah dalam nas Imam Ahmad pengharaman nikah tidak berlaku jika masuknya air susu dengan cara suntikan atau penetesan air susu ke mata, hidung, atau luka ditubuh karena hal tersebut tidak termasuk rad $\} a^{\prime}$ ah dan tidak disebut juga menyuplai makanan sehingga dalam hal it tidak ditetapkan sebagai hukum rad\}a'ah. Sedangkan menurut Malikiyah berpendapat dikatakan $\mathrm{rad}$ \}a'ah dengan suntikan air susu sebagai suplai makanan, bukan hanya sekedar masuknya air susu kedalam perut melalui suntikan. (Wahbah Zuh \}aily: 1997, 6637).

4) Air susu yang diminum tidak tercampurkan dengan apapun, maka, jika yang lebih banyak adalah susu wanita tersebut maka diharamkan menikah dari keduanya (yang menyusui dan yang disusui). (M. Abdul Ghoffar: 1998, 474) Menurut Hanafiyah dan Malikiyah jika air susu tercampur dengan cairan lain dan yang dominan air susunya maka haram dinikahi. Menurut Syaficeiyah pendapat yang azhar dan ulama Hanabilah dlam pendapat yang rajah menganggap air susu yang bercampur dengan yang lain hukumnya sama dengan air susu murni yang tidak bercampur dengan apapun, baik bercampur dengan makanan maupun minuman dan lainnya asalkan air susu tetap masuk kedalam perut. Menurut Imam Abu Hanifah berbeda pendapat dengan Muhammad dan Abu Yusuf berpendapat bahwa air susu yang bercampur dengan makanan tidak menjadikan hukum rad\}a'ah yang mengharamkan pernikahann, baik air susu yang dominan maupun makananya. Disebabkan karena makanan meskipun dalam jumlah sedikit akan tetapi dapat mengubah kekuatan pengaruh susu hingga menjadi lemah dan tidak cukup untuk suplai makanan bayi. (Wahbah Zuh\}aily: 1997, 6637).

5) Meneteknya masih dalam usia bayi, kesepakatan ulama empat madzab jika yang menetek sudah besar maka tidak termasuk dalam hukum rad \}a'ah dan batasanya hingga usia dua tahun. Dalil mayoritas ulama yang berpendapat bahwa hukum rad\}a'ah hanya berlaku bagi bayi adalah sebagai berikut. Pertama dalam firman Allah SWT surat al-Baqarah ayat 233 


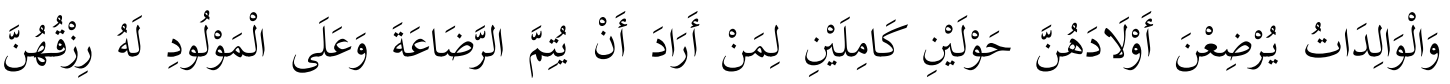

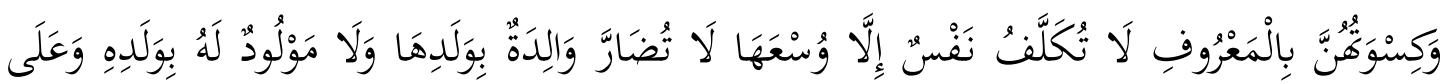

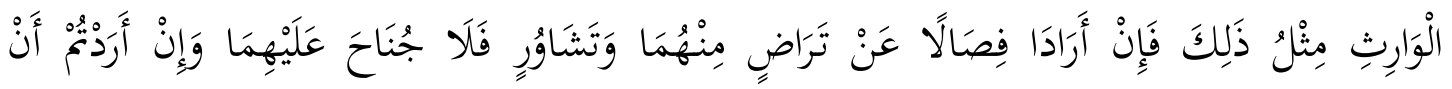

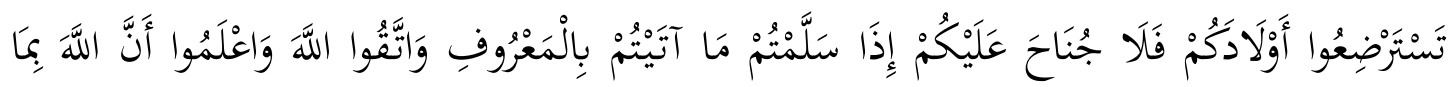

$$
\begin{aligned}
& \text { تَعْمَلُونَ بَصِيرِ }
\end{aligned}
$$

Terjemahnya:

Para ibu hendaklah menyusukan anak-anaknya selama dua tahun penuh, yaitu bagi yang ingin menyempurnakan penyusuan. Dan kewajiban ayah memberi makan dan pakaian kepada para ibu dengan cara ma'ruf. Seseorang tidak dibebani melainkan menurut kadar kesanggupannya. Janganlah seorang ibu menderita kesengsaraan karena anaknya dan seorang ayah karena anaknya, dan warispun berkewajiban demikian. Apabila keduanya ingin menyapih (sebelum dua tahun) dengan kerelaan keduanya dan permusyawaratan, maka tidak ada dosa atas keduanya. Dan jika kamu ingin anakmu disusukan oleh orang lain, maka tidak ada dosa bagimu apabila kamu memberikan pembayaran menurut yang patut. Bertakwalah kamu kepada Allah dan ketahuilah bahwa Allah Maha Melihat apa yang kamu kerjakan.

Pada ayat itu menjelaskan bahwa sempurnakanya masa menyusui adalah dua tahun.

1. Bilangan dan Bentuk Susuan yang Dapat Mengharamkan

عن عائشة الله ر.ض قالت:قال رسول الله صلى الله عليه و سلم: لا تحرم المصة أو المصتان (رواه

(Muslim bin Hajjaj Abu al-Hsan al-Qusyairi al-Naisaburi: t.th, 1018.)(مسلم)

Artinya:

Dari Aisyah Mengatakan bahwa?." Nabi SAW bersabda: " Sekali susuan atau dua kali susuan atau sekali hisapan dan Dua kali Hisapan tidaklah menjadikan mahram.'(Riwayat Muslim)

$$
\begin{aligned}
& \text { عن أم الفضل قالت دخل أعرابي على نبي الله صلى الله عليه و سلم وهو في بيتي فقال يا نبي الله } \\
& \text { إني كانت لي امرأة فتزوجت عليها أخرى فزعمت امرأتي الأولى أهما أرضعت امرأتي الحدثي رضعة } \\
& \text { أو رضعتين فقال نبي الله صلى الله عليه و سلم : لا تحرم الإملاجة والإملاجتان (رواه مسلم) . }
\end{aligned}
$$


(Muslim bin Hajjaj Abu al-H\{san al-Qusyairi al-Naisaburi: t.th, 1074.)

Artinya:

Dari Ummu Fadhl Mengatakan bahwa "Seorang Arab pedalaman datang kepada Nabi yang ketika itu beliau ada dirumahku, lalu orang itu berkata, "Wahai Nabi! Saya mempunyai seorang isteri, lalu saya menikah lagi. Kemudian Isteriku yang meyakini bahwa dia pernah menyusui isteriku yang muda dengan sekali atau dua kali susuan?." Nabi SAW bersabda: “ Sekali hisapan dan Dua kali Hisapan tidaklah menjadikan mahram."(Riwayat Muslim)

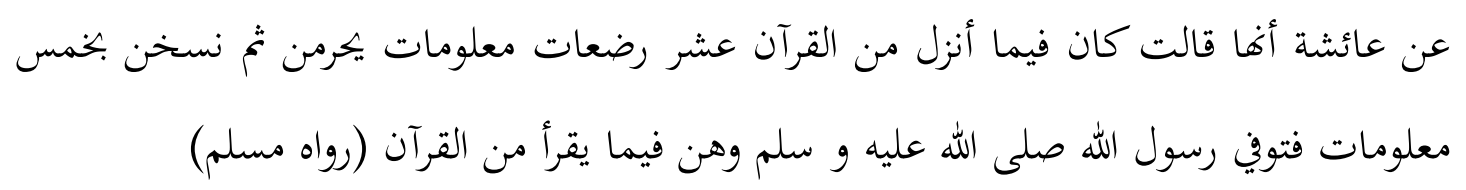

(Muslim bin Hajjaj Abu al-Hsan al-Qusyairi al-Naisaburi: t.th, 1075.)

Artinya:

Aisyah RA berkata, semua susuan yang menyebabkan kemuhriman adalah sepuluh kali susuan seperti yang tersebut di sebagian ayat Al Qur'an . kemudian dinasakh menjadi lima susuan oleh ayat Al Qur'an. Setelah itu Rasulullah wafat dan ayat-ayat Al Qur'an tetap dibaca seperti itu." (Riwayat Muslim).

$$
\begin{aligned}
& \text { عن ابن مسعود ر.ض قال: قال رسول الله صلى الله عليه و سلم " لارضاع إلاماانشز } \\
& \text { العظم,وأنبت اللحم" ( أخرجه أبوداود) }
\end{aligned}
$$

(Abu Dawud Sulaiman bin al-Asy'ats bin Ishaq bin Basyir bin Syaddad bin 'Amru alAzdi al-Sajistani: t.th, 222)

Artinya:

Dari Ibnu Mas'ud R.A, dia berkata: Tida penyusuan yang dapat mengharamkan kecuali penyusuan yang menguatkan tulang dan menumbuhkan daging. (Riwayat Abu Dawud) 


$$
\begin{aligned}
& \text { وعن عائشة رضي الله عنها أن رسول الله صلى الله عليه وسلم دخل عليها وعندها رجل، فتغيّر } \\
& \text { وجه النبي صلى الله عليه وسلم فقالت:( يا رسول الله إنه أخي من الرضاعة، فقال: انظرُكَ مَنْ }
\end{aligned}
$$

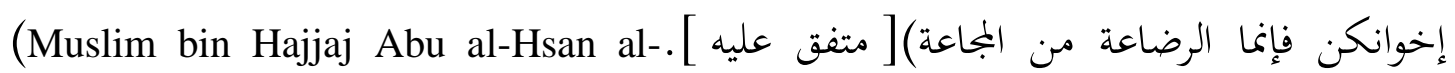

Qusyairi> al-Naisabu>ri: t.th, 1075.)

Artinya:

Dari Aisyah R.A, dia berkata: lihatlah saudara-saudaramu (sesusuan), sebab sesusuan itu dari rasa lapar. (Muttafaq Alaih)

$$
\begin{array}{r}
\text { وعن أم سلمة رضي الله عنها قالت: قال رسول الله صلى الله عليه وسلم: لا يحرم من الرضاعة إلا الأمعاء في الثدي وكان قبل الفطام. (رواه الترمذي وصححه هو والحاكم) }
\end{array}
$$

Dari Ummu Salamah R.A, dia berkata: Rasulullah SAW bersabda: Tidak haram sesusuan kecuali masuk pada usus, dan anak belum disapih. (Riwayat Tirmidzi. Di sahihkannya bersama Hakim)

$$
\begin{aligned}
& \text { عن زياد السهمي قال: غهى رسول الله صلى الله عليه وسلم أن تسترضع الحمقى,( أخرجه } \\
& \text { أبوداود, وهومرسل, وليست لزيادة صحبة) }
\end{aligned}
$$

Artinya:

Dari Ziyad Assahmi, dia berkata: Rasulullah SAW melarang meminta kepada perempuan yang bodoh untuk menyusui. (Riwayat Abu Dawud. Hadits ini Mursal karena Ziyad bukan Sahabat)

Ada beberapa hal yang dapat kita garis bawahi, antara lain adalah:

a. bahwa sekali atau dua kali hisapan atau susuan tidaklah mengakibatkan terjadinya mahram.

b. Kedua yang mengakibatkan Mahram adalah tiga kali hisapan atau susuan. ini berdasarkan hadis yang disampaikan Ummu Fadhl, dan pendapat ini adalah dari Abu Tsaur, Ibnu Munzir, dan Daud serta Ahmad dalam suatu riwayat lain.

c. Bahwa yang dapat mengakibatkan Mahram adalah lima kali Susuan keatas, karena itu merupakan batas rasa lapar bagi bayi. ini yang dikemukakan beberapa Ulama dikalangan Sahabat seperti, Ibnu Mas'ud, Ibnu Zubair, Atha', dan Thawus, 
serta ulama Mazhab Yaittu Asy-Syafi'I, dan Ahmad. ini berdasarkan apa yang disampaikan oleh Aisyah. Bahwa penyusuan yang mengharamkan juga harus masuk ke usus dan dapat menguatkan tulang.

d. Anak tidak boleh disusukan pada perempuan yang kurang cerdas.

2. Menyusui Orang Dewasa

$$
\begin{aligned}
& \text { عن عائشة ر.ض قالت:جأت سهلة ابنة سهيل,فقالت: يا رسول الله, إن سالما مولى أبي حذيفة } \\
& \text { معنا في بيتنا, قد بلغ ما يبلغ الرجال وعقل ماعقلوا وإنه يدخل علينا وإن أظن أن في نفس أبي } \\
& \text { حذيفة من ذلك شيئا فقال لها النبي صلى الله عليه و سلم أرضعيه تحرمي عليه ويذهب الذي في } \\
& \text { نفس أبي حذيفة فرجعت فقالت إبي قد أرضعته فذهب الذي في نفس أبي حذيفة (رواه مسلم) }
\end{aligned}
$$

Artinya:

Dari Aisyah R.A, berkata: Bahwa salim maula Abu Huzaifah pernah berada bersama Abu Huzaifah dan keluarganya dirumah mereka. lalu datanglah Sahlah bin Suahail (isteri Abu Huzaifah) kepada Nabi SAW, kemudian ia berkata, sesungguhnya Salim telah mencapai usia dewasa, dan saya mengira Abu Huzaifah merasa tidak enak (agak cemburu) kalau Salim masuk kerumah kami." Maka Nabi SAW berkata kepada SAhlah, "Susuilah dia agar kamu menjadi mahram baginya, sehingga Abu Huzaifah tidak lagi merasa cemburu." kemudian Sahlah bin Suhail pulang menemui Abu Huzaifah, dan ia berkata, "Sesungguhnya saya telah menyusui Salim." lalu hilanglah kekhawatiran Abu Huzaifah." (Riwayat Muslim).

$$
\begin{aligned}
& \text { عن زينب بنت أبي سلمة أخبرته أن أمها أم سلمة زوج النبي صلى الله عليه و سلم كانت تقول } \\
& \text { أبي سائر أزواج النبي صلى الله عليه و سلم أن يدخلن عليهن أحدا بتلك الرضاعة وقلن لعائشة } \\
& \text { و الله مانرى هذا إلا رخصة أرخصها رسول الله صلى الله عليه و سلم لسالم خاصة فما هو بداخل } \\
& \text { علينا أحد بهذه الرضاعة ولا رائينا(رواه مسلم) }
\end{aligned}
$$


Artinya:

Dari Zainab binti Ummu Salamah, Bahwa ibunya, yakni Ummu Salamah (isteri Nabi SAW) berkata, "semua isteri-isteri Nabi menolak untuk memasukkan Laki-laki yang pernah mereka susui pada usia dewasa kedalam rumah mereka. mereka mengatakan kepada Aisyah, Demi Allah! apa yang berhak kepada Salim dengan Sahlah tersebut hanyalah Dispensasi yang diberikan Rasulullah, SAW khusus untuk Salim, sehingga laki-laki yang pernah kita susui pada usia dewasa seperti itu tidak boleh masuk kerumah kita dan kita tidak boleh melihatnya." (Riwayat Muslim).

Menurut ibnu Taymiyyah pada hadis yang pertama menyatakan bahwa menyusui orang dewasa mengakibatkan mahram antara orang yang menyusui dengan orang yang disusui, dan hadis ini mencapai tingkat Mutawatir. akan tetapi Jumhur Ulama berpendapat bahwa hukum susuan hanya hanya mengenai anak yang masih kecil. Tentang hadis ini hanya berlaku pada mereka saja, yakni Salim dan Sahlah. Sebagaimana keterangan yang disampaikan Aisyah dalam hadis kedua dari pembahasan ini. Hal ini dikuatkan juga oleh Asy-Syaukani.

3. Wanita Dapat Menjadi Saksi Dalam Hal Susuan

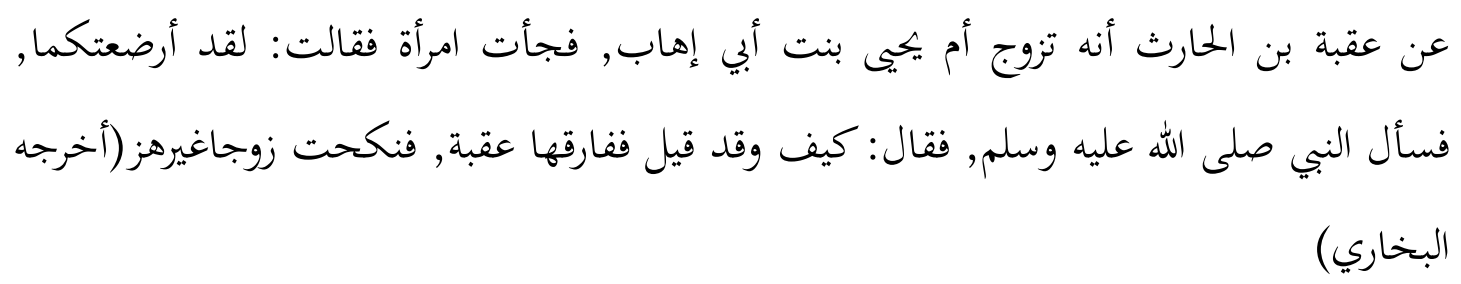

Artinya:

Dari Uqbah bin Harits, bahwasanya dia mengawini Ummu Yahya binti Abu Ilhab. lalu ada seorang perempuan datang dan berkata: Saya betul-betul menyusui kamu berdua. lalu saya bertanya kepada Nabi SAW, beliau menjawab: bagaimana lagi sudah ada orang berkata. Lalu Uqbah menceraikannya, dan Ummu Yahya kawin dengan lelaki lain. (Riwayat Bukhari)

Hadis ini menyatakan bahwa kesaksian seoarng wanita tetang susuan dapat diterima dan wajib diamalkan ini diriwaytkan dari Usman, ibnu Abbas, Az-Zuhri, AlHasan, Ishaq, Al-Auza'I, Ahmad dan Abu Ubaid. diriwayatkan dari golongan 
Syafi'iyah dan Hanafiyah bahwa wajib mengamalkan persangkaan dalam masalah nikah. walaupun menerima kesaksian seorang wanita dalam masalah Radha'ah, berlawanan dengan maslahah biasa akan tetapi kita harus menerimanya karna telah ada nash yang khusus.

4. Hadiah Kepada Ibu Susuan

$$
\begin{aligned}
& \text { عن حجاج بن حجاج عن أبيه قال : قلت يارسول الله ما يذهب عني مذمة ( يريد ذمام الرضاع } \\
& \text { وحقه ) الرضاعة ؟ قال " الغرة العبد أو الأمة " قال النفيلي حجاج بن حجاج الأسلمي وهذا } \\
& \text { لفظه ضعيف (رواه أبو داود) }
\end{aligned}
$$

Artinya:

Diriwayatkan dari Al-hajjaj ibn hajjaj ibnu Malik ibn Aslami, dia berkata bahwa saya bertanya kepada Rasulullah "apakah kiranya yang dapat membalas budi sebagai rasa tanggung jawabku terhadap ibu susuanku?." Nabi SAW menjawab, " menghadiahkan seoarng budak laki-laki atau budak perempuan.’'(riwayat Abu Daud)

Dari hadis ini diterangkan bahwa memberikan hadiah diluar upah kepada ibu susuan sebagai ungkapan terima kasih adalah dianjurkan, dan ini telah menjadi kebiasaan bagi orang-orang terdahulu.

\section{Hikmah Pengharaman Akibat Persusuan}

Salah satu akibat susuan dikarenakan karena beberapa bagian tubuh manusia terbentuk dari susu. Susu seorang perempuan menyebabkan tumbuhnya daging anak yang dia susui dan membuat ukuran tulangnya menjadi membesar. Sebagaimana yang disebutkan dalam hadis

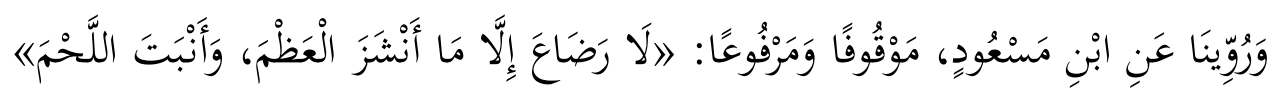

(Ahmad bin al-Husain bin 'Ali bin Musa bin al-Khusraujirdi al-Kharasani: $1989,177)$

Artinya:

Tidak dinamakan menyusu kecuali apa yang dapat memperbesar tulang dan menumbuhkan daging

Sesungguhnya pembesaran tulang dan penumbuhan daging akibat pasokan makanan yang berupa susu. Dengan demikian, maka perempuan yang menyusui 
menjadi ibu susuan karena dia adalah bagian dari anak itu secara hakikat (Wahbah Zuhaily: 1997, 6637).

PENUTUP

\section{A. Kesimpulan}

Dari beberapa hadis diatas dapat diambil istimbat hukum bahwa orang-orang yang diharamkam karna susuan ada tujuh orang yakni: Ibu susuan, Saudara perempuan susuan, Anak perempuan, Saudara dari ayah susuan, Saudara perempuan dari ibu. Anak perempuan dari saudara laki-laki, Anak perempuan dari saudara perempuan. Para ulama sepakat atas pengharaman nikah dengan saudara sepersusuan tetapi mereka berbeda pendapat soal syarat rada'ah dan kadar air susu yang mengharamkan nikah. Salah satu akibat susuan dikarenakan karena beberapa bagian tubuh manusia terbentuk dari susu. Susu seorang perempuan menyebabkan tumbuhnya daging anak yang dia susui dan membuat ukuran tulangnya menjadi membesar.

\section{DAFTAR PUSTAKA}

AL-Qur'an al-Karim

al-Asqalani, Ahmad bin Ali bin Hajar. Syarah Fath al-Bari. Juz IX. Cet. I; Bairut: Dar al-Kutub Ilmiyyah. 1989.

al-Jaziri, Abdurrah\}man. Kitab al-Fiqh Ala al-Madzab al-Arba'ah. Juz IV. Beirut: Dar al-Fikr.

al-Ju'fi, Muhammad bin Ismail Abu 'Abdullah al-Bukhari. Sahih al-Bukhari, Juz III. Cet. I; Dar Tuq al-Najjah\}. 1422.

al-Kharasani, Ahmad bin al-Husain bin 'Ali> bin Musa bin al-Khusraujirdi. Sunan al-Baihaqi. Juz III. Cet. I; Pakistan: Jami’ah al-Dirasat al-Islamiyyah. 1989

Ghoffar, M. Abdul. Fiqih Wanita. Jakarta: Pustaka al-Kausar. 1998.

Kementerian Agama. Al-Qur'an dan Terjemahnya. Cet. I; PT. Tiga Serangkai Pustaka Mandiri, 2013.

Khon, Abdul Majid. Ulumul Hadis. Cet. II; Jakarta: Amzah. 2009.

Mughniyah, Muhammad Jawad. al-Fiqh 'ala al-Madzabiyah al-Khamsah. Jakarta: Lentera. 1996.

Muhammad Ibn Ali Ibn Muhammas al-Syaukani. Nail al-Authar. Juz V. Beirut: Da>r al-Jil. 1995.

Wijawa, Utang. Ilmu Hadis. Jakarta: Media Pratama. 1996.

Zakariyya, Al-Husain Ahmad bin Faris. Maqayyis al-Lugah. Juz II. Cet. I; Bairut: Dar al-Jalil. 1979.

Zuhaily, Wahbah. al-Figh al-Islam wa Adillatuh. Beirut: Dar al-Fikr al-Ma'asir. 1997. 